\title{
Vein Mineralogy and Hydrothermal Gold Mineralization at the Kyaw Soe Thu Prospect in the Wabo Deposit, Mandalay Region, Central Myanmar
}

\author{
Kyaw Min Khaing1,2*, Kotaro Yonezu ${ }^{1}$, Thomas Tindell1, Koichiro Watanabe ${ }^{1}$, May Thwe Aye ${ }^{2}$ \\ ${ }^{1}$ Department of Earth Resources Engineering, Kyushu University, Fukuoka, Japan \\ ${ }^{2}$ Department of Geology, University of Yangon, Yangon, Myanmar \\ Email: ^kyawmin@mine.kyushu-u.ac.jp
}

How to cite this paper: Khaing, K.M., Yonezu, K., Tindell, T., Watanabe, K. and Aye, M.T. (2020) Vein Mineralogy and Hydrothermal Gold Mineralization at the Kyaw Soe Thu Prospect in the Wabo Deposit, Mandalay Region, Central Myanmar. Open Journal of Geology, 10, 137-154. https://doi.org/10.4236/ojg.2020.102008

Received: January 9, 2020

Accepted: February 14, 2020

Published: February 17, 2020

Copyright $\odot 2020$ by author(s) and Scientific Research Publishing Inc. This work is licensed under the Creative Commons Attribution International License (CC BY 4.0).

http://creativecommons.org/licenses/by/4.0/

(c) (i) Open Access

\begin{abstract}
The Kyaw Soe Thu Prospect is a part of the Wabo deposit which is situated along Mogok Metamorphic Belt (MMB) in Central Myanmar. Gold bearing veins are hosted in the banded garnet-biotite gneiss, calc-silicate, marble and granitoid of the Wabo area. The granitic rocks intruded into banded garnet-biotite gneiss. The MMB was intensely deformed and it is a highly fractured metamorphic terrain in which metamorphic facies ranges from amphibolite to granulite facies. Gold mineralization at the Kyaw Soe Thu Prospect in the Wabo deposit occurred in the forms of gold-quartz veins. The quartz veins are a few centimeters in width. The color of the quartz vein at the Kyaw Soe Thu Prospect is commonly smoky and milky. The quartz vein exhibits chalcedonic, saccharoidal and granular textures. Three mineralizations were indicated. Stage I is the thin layered crustiform chalcedonic quartz. Stage II is chalcedonic quartz vein and stage III is Ankerite-quartz-sericite vein. Stage II and stage III are gold rich hydrothermal stages, and Ankerite-quartz-sericite veins were formed with a small amount of sericites in the Kyaw Soe Thu Prospect. The Ankerite-quartz-sericite veinlets range from a centimeter up to three centimeter in width within the stage II chalcedonic quartz vein. Textures of mineralized quartz vein samples were petrographically examined. The textures include a feathery texture that is most closely associated with electrum in both stage II chalcedonic quartz veins and stage III Ankerite-quartz-sericite veins. Ankerite varies in color from pink, white to buff. Among them, pink color is more common in the Kyaw Soe Thu Prospect. Ankerite in the Kyaw Soe Thu Prospect exhibits rhombohedral idiomorphic, which exhibits growth patterns. Ore minerals of the veins are electrum, pyrite, galena, and trace amount
\end{abstract}


of very fine-grained chalcopyrite. On the basis of textures of the chalcedonic quartz veins, the Kyaw Soe Thu Prospect is ascribed to be a low-sulfidation epithermal deposit.

\section{Keywords}

Gold Mineralization, Ankerite, Electrum, Wabo Deposit, Myanmar

\section{Introduction}

Gold and copper occurrences are widely distributed in Myanmar. They are 1) Mesothermal gold mineralization, porphyry-type gold and copper and its related epithermal gold mineralization along the Central Volcanic Belt (Wuntho-Popa Magmatic Arc); 2) Sediment-hosted epithermal gold mineralization along the Sagaing Fault Zone, and 3) Mesothermal to epithermal gold mineralization in Mogok Metamorphic Belt (MMB) in the south [1] [2] [3]. The Wabo deposit is one of the significant primary gold deposits in the Thabeikkyin-Singu area in Mogok-Mandalay-Mergui Belt (MMMB) [3] (Figure 1) that is located about 50 $\mathrm{km}$ to the north of Mandalay, Central Myanmar. The area is situated at southern continuation of the (MMB). The MMB was initially named by [4] and also has been known as (MMMB) which is one of the most significant metallogenic provinces of Myanmar [3] (Figure 1). The MMB also hosts gems deposits such as Ruby and Sapphire [5] [6] together with some major gold and base metal deposits [7] (Figure 2). Most gold mineralization in the MMB is orogenic gold type and low-sulfidation epithermal gold type, as well as skarn gold-copper type. The breccia and vein type gold deposits are also hosted by the MMB. The shear related fracture zone-type gold deposits are also found in the MMB. Along the $\mathrm{MMB}$, there are several gold occurrences such as Thayetsu (orogenic gold), Thabeikkyin gold field (mesothermal to epithermal with some skarn type gold), Phayaung Taung (orogenic gold), Modi Taung (orogenic gold), and Shwekyin and Meyon (orogenic gold) (Figure 2) [3] [7] [8] [9] [10]. It is noted that gold mineralization of the MMB is preferentially confined to the shear zones and fracture systems. The host rocks vary from relatively undeformed and unmetamorphosed carbonaceous and calcareous sedimentary rocks to highly deformed metamorphic rocks of mostly Phanerozoic [10]. Especially, gold mineralization in the Wabo area occurred as gold-quartz veins and mineralized breccia, it is hosted by the garnet-biotite gneiss. This study aims to understand vein texture, characteristics of ore minerals, and mineral paragenesis of the Kyaw Soe Thu Prospect in the Wabo area.

\section{Geological Setting}

Myanmar is positioned at the junction of the Alpine-Himalayan Orogenic Belt and the Indonesian Island Arc System [3] (Figure 1). It is a tectonically complex 


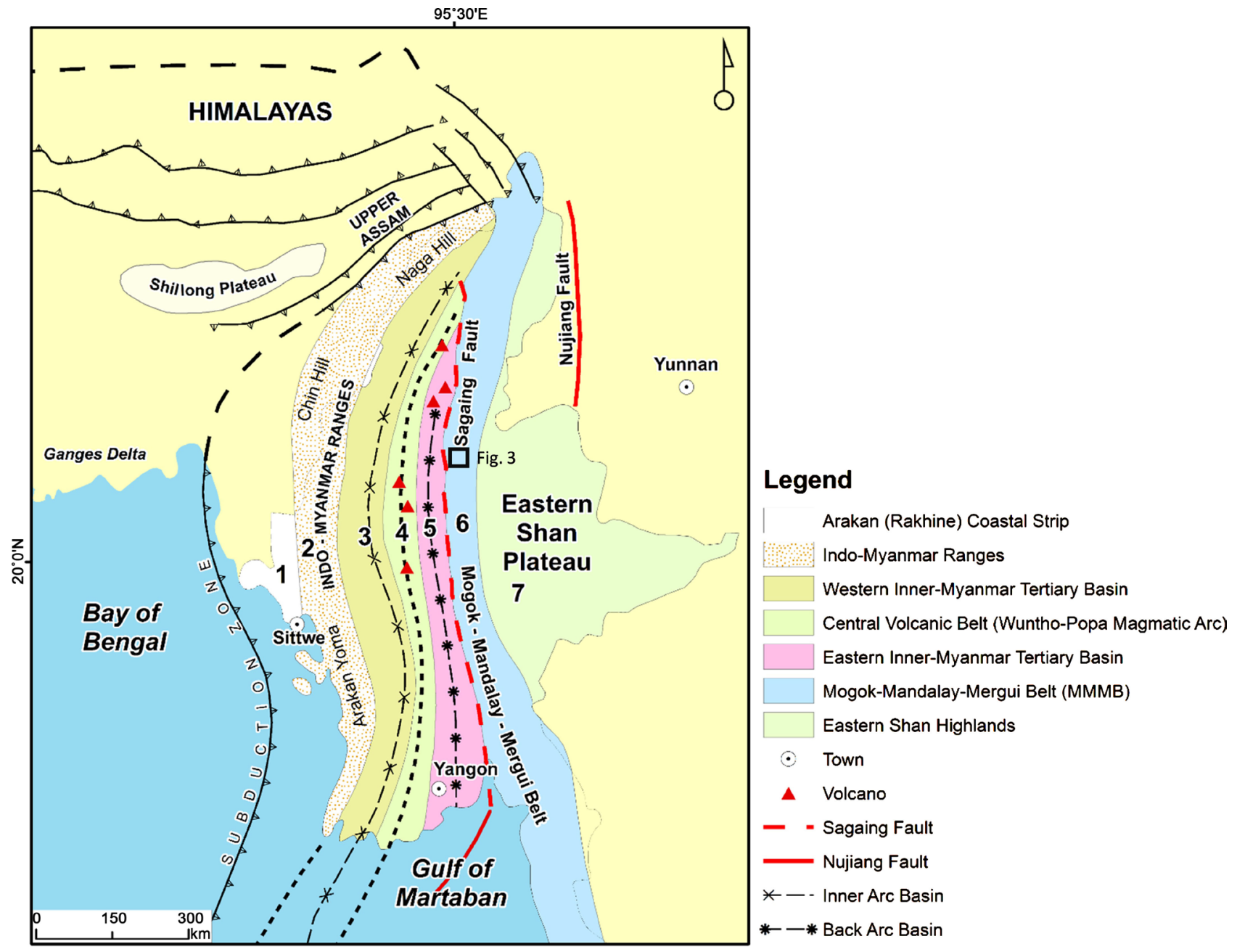

Figure 1. Regional setting and tectonic domains of Myanmar (modified after [3]). 1. Arakan (Rakhine) Coastal Strip; 2. Indo-Myanmar Ranges; 3. Western Inner-Myanmar Tertiary Basin; 4. Central Volcanic Belt (Wuntho-Popa Magmatic Arc); 5. Eastern Inner-Myanmar Tertiary Basin; 6. Mogok-Mandalay-Mergui Belt (MMMB); 7. Eastern Shan Highlands, and black rectangular shows current research area.

region composed of microplates such as Sibumasu, West Myanmar, and India. In northern Myanmar, the orogenic belt is bent around the Eastern Himalayan Syntaxis into a North-South direction and passes southwards through the IndoMyanmar Ranges into the Andaman and Nicobar Islands [11]. Tectonogeographically, Myanmar can be divided into two geological provinces: Eastern Province and Western Province by a 1200 km long, N-S trending, dextral Sagaing Fault [3] [4] (Figure 1 and Figure 2). The Eastern Province belongs to the Shan-Thai Block (Shan Plateau) [12], also known as the Sibumasu Block, together with Western Malaysia and Eastern Sumatra [13], whereas the Western Province, which belongs to the West Burma Terrane, comprising the Indo-Myanmar Ranges and the Wuntho-Popa Magmatic Arc [3] [4] (Figure 1 and Figure 2) system overlying the Cretaceous-Eocene strata [14] [15].

The Western Myanmar Province which is also known as the Burma Microplate was originated from Gondwana, and later drifted, accreted and collided 


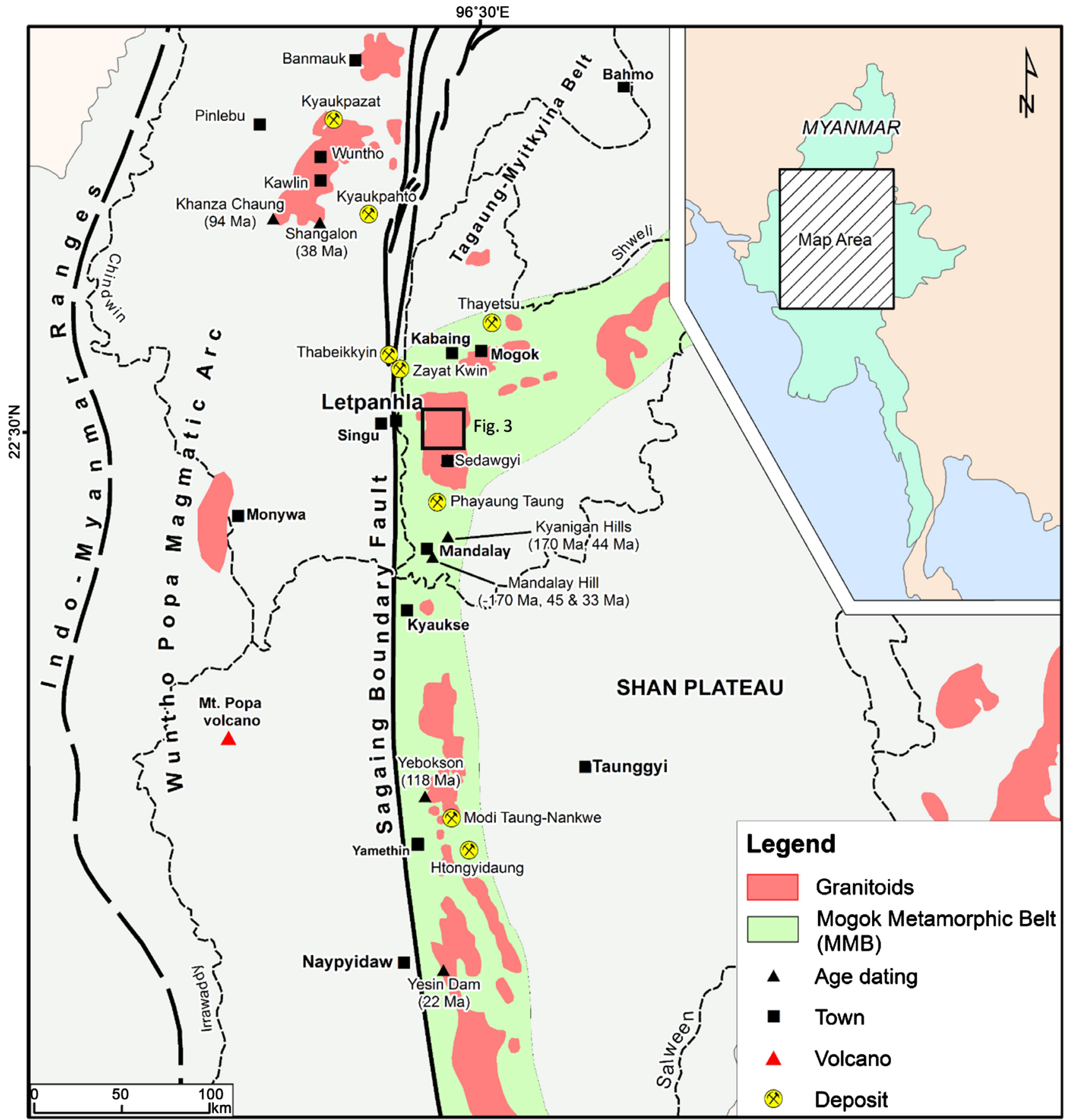

Figure 2. Map of upper Myanmar showing outline of the Mogok Metamorphic Belt (MMB), distribution of major granitoids and some gold occurrences (modified from [4]), black rectangular denotes (Figure 3).

with Eurasia in either the latest Triassic [13] or at the earliest Triassic [16]. The MMB occurs as a narrow (30 - $40 \mathrm{~km}$ wide) and elongated (1500 km long) belt of metamorphic rocks [14] along the eastern margin of Western Province [3] [4] (Figure 1 and Figure 2), including Kyanite and Sillimanite schists and granites. The MMB also lies along the Western margin of the Shan Plateau in Central Myanmar and extends Northwards from the Mogok region to the Himalayan Syntaxis and continues Southwards through the Kyaukse region [4] (Figure 2) 
to Martaban [3] (Figure 1). The formation of the MMB is considered to be related to the Indian-Asian continental collision events [4]. The oblique convergence and collision between the Indian and Eurasian plates generated strike-slip faults, such as the Nujiang Fault [3] (Figure 1), which traverses western Yunnan, China and the Sagaing Fault that truncates the Myanmar Central Basin [17]. Such Faults extensively disrupted the original orogenic architecture of mainland SE Asia, developing secondary orogenic collages or terranes, such as the MMB [18], and the Shan-Thai Block [17].

The MMB comprises a sequence of high-grade meta-sedimentary and meta-intrusive rocks, representing a foliated amphibolite-grade regionally metamorphosed belt [18] [19], and the MMB is considered as a metamorphic core complex, tectonically unroofed during crustal extension on low-angle detachment faults [14] [20].

The gem-mining in the Mogok area is characterized by a sequence of undifferentiated high-grade metamorphic rocks. The abundant unit is banded gneiss with biotite, garnet, sillimanite and oligoclase. Marble mainly consists of calcite, while dolomitic marbles are limited. Some marbles contain ruby, whereas others have spinel, forsterite or diopside, or phlogopite-graphite. Rutile, graphite, calcite, paragasite, zircon, titanite, apatite, scapolite, spinel and zircon are also present as inclusions in Mogok rubies [6]. Biotite granites are widely exposed at Kabaing and Thabeikkyin [4] [5] [21] (Figure 2).

Several radiometric ages of the Mogok metamorphic rocks in the Mandalay-Mogok regions were reported in the literatures. [4] undertook the first SHRIMP geochronology of the metamorphic and magmatic rocks along the $\mathrm{MMB}$ and reported multiple ages as early as Jurassic to Miocene. Most $\mathrm{U}-\mathrm{Pb}$, $\mathrm{Th}-\mathrm{Pb}$, and $\mathrm{U}-\mathrm{Th}-\mathrm{Pb}$ ages display recrystallization during Middle Eocene to Early Oligocene $(43.8 \pm 1.0-27 \pm 0.8 \mathrm{Ma})$, except for older ages that might be derived from detrital and /or inherited grains [22]. On the other hand, Ar-Ar ages, which probably represent the cooling after peak metamorphism, indicated Late Oligocene-Early Miocene ages (24.0 $\pm 0.8-16.0 \pm 1.0 \mathrm{Ma})$ [22]. Metamorphic ages by CHIME reported the high temperature-type metamorphism in Central Myanmar, probably reached peak temperature conditions in the Late Eocene, then subsequently shifted to the exhumation and/or cooling stage [22]. [4] also reported SHRIMP U-Pb Zircon ages of $30.9 \pm 0.7 \mathrm{Ma}$ and $22.4 \pm 0.4 \mathrm{Ma}$ from hornblende syenite (Mandalay Hill area) and biotite syenogranite (Yesin Dam area) [4] (Figure 2), respectively. [15] reported younger zircon U-Pb ages of $20.7 \pm 0.5 \mathrm{Ma}$ and 17.0 Ma from a dacite porphyry dyke in the Payangazu area and a biotite granite dyke in the Sedawgyi area [3] (Figure 2), respectively, and considered that uplift and cooling of the metamorphic rocks occurred from Late Oligocene to Early Miocene.

\section{Local Geology of the Wabo Deposit}

The geology around the Wabo gold deposit is shown in Figure 3. The rock units 


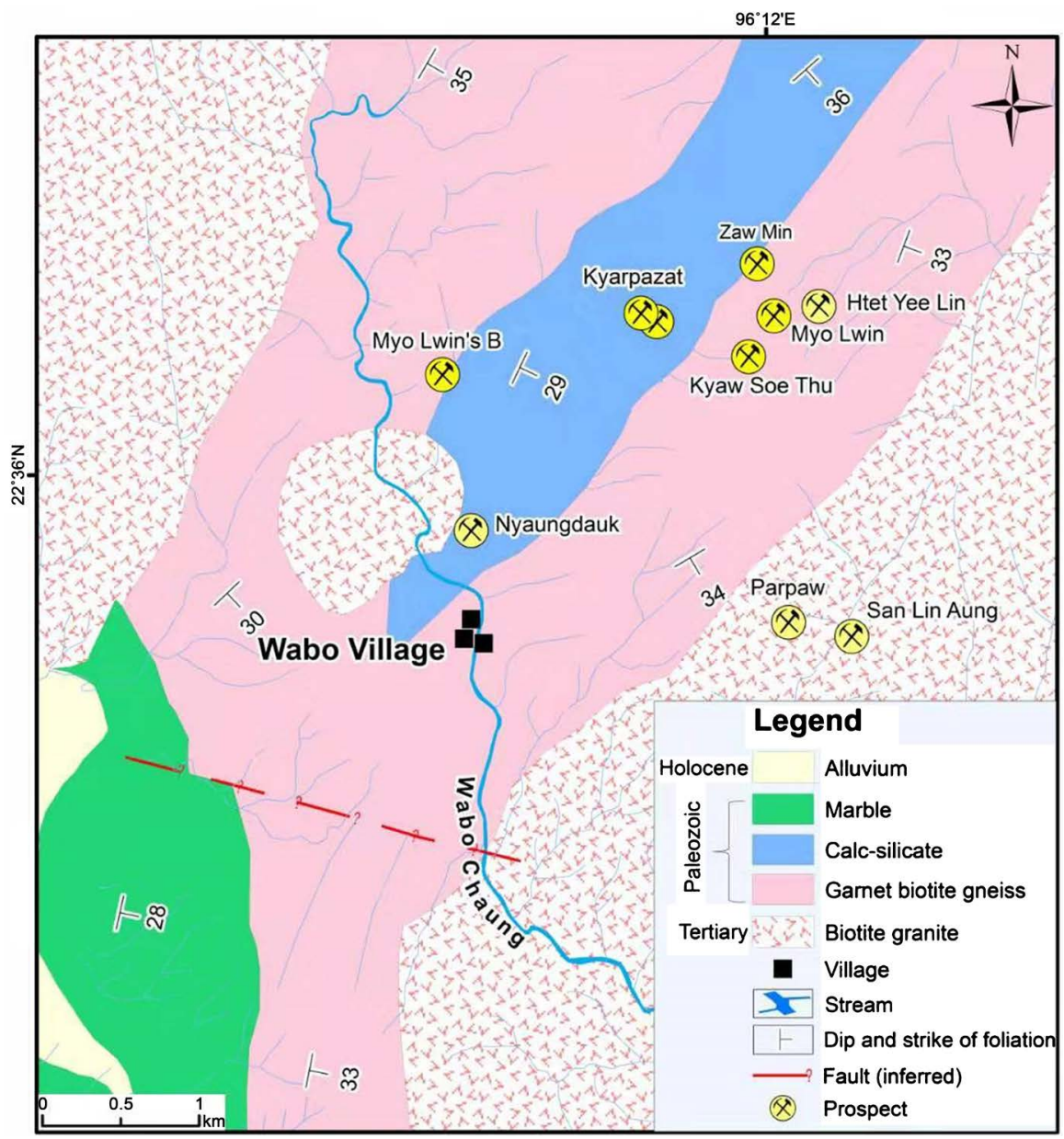

Figure 3. Simplified geological map of the Wabo gold deposit with local artisanal working sites and prospects (based on $93 \mathrm{~B} / 2$ one inch map).

are garnet biotite gneiss, marble, calc-silicate rock and biotite granite. The Wabo area includes several local gold workings. A group of artisanal workings such as Zaw Min, Myo Lwin, Htet Yee Lin, Kyarpazat and Kyaw Soe Thu are present in the north and Nyaungdauk in the southwest and Parpaw and San Lin Aung in the southeast of the Wabo area (Figure 3). In these local gold workings, the Kyaw Soe Thu Prospect is the focus in this paper.

The Wabo area is mainly composed of metamorphic and igneous rocks (Figure 3). Calc-silicate rock and gneiss are widely distributed in the northern and central parts of the area. The age of the protolith of the metasedimentary rock was reported as Late Cambrian from U-Pb age on the gneiss [15]. However, fossils evidences in marble near Kyaukse suggested Carboniferous age [23]. The igneous rock units are generally exposed in the eastern and central parts of the Wabo area. The majority of igneous rocks of the investigated area is biotite granite intruded the metamorphic rocks. Radiometric dating on igneous and metamorphic rocks of the MMB includes an Ar-Ar age of biotite at $15.8 \mathrm{Ma}$ for the Kabaing Granitoid and Ar-Ar ages of biotite yielded three nearby metamorphic rocks ranging from 16.5 to $19.5 \mathrm{Ma}$ [18]. The several granulites of the MMB 
were considered to have been emplaced and tectonically exhumed in the Late Miocene following uplifting related to a continental collision between India and Asia [20] [24].

\section{Lithology and Nature of Outcrops}

In this section, the nature and lithological characteristics of the different rock units of the Wabo deposit are described below.

Garnet biotite gneiss: The gneiss unit in the area exhibits numerous boudinage and augens with varying size of garnet porphyroblasts. The segregation layers are prominent in this rock unit. Most of biotite crystals are larger than 0.5 $\mathrm{mm}$ in length. Curved biotite flakes observed around garnet grains seem to be caused by the development of garnet porphyroblasts. Banded gneiss is also exposed in the mine workings. Garnet grains in the rock unit are euhedral to anhedral ranging in size from $\mathrm{mm}$ to $\mathrm{cm}$. The banded gneiss is medium- to coarse-grained with feldspar, quartz, biotite, garnet and cordierite. This unit commonly exhibits a banded structure reflecting compositional and/or structural variations. Augen texture is prominent in this unit both in foliation plane and within the band. Rotation of augens during growth, due to shearing, leads to sigmoidal inclusion trails. Drag folding is often observed in the garnet-cordierite biotite gneiss. On the foliation margin, garnets form as aggregated grains.

Marble and calc-silicate rocks. The marble unit is well exposed in the eastern part of Wabo. It is a massive rock unit with phlogopite and graphite. This unit is medium- to coarse-grained, hard and compact and generally exhibits criss-crossed structure. It also exhibits granulose texture. The calc-silicate rock is well characterized as a bedded unit and consists of diopside and calcite. Most of the diopside are rounded grains. This unit exhibits characteristic features plastic deformation such as drag fold, and tight folds. It is fine- to medium-grained, hard and compact, and shows remarkable foliation. The foliation bands range from $0.7 \mathrm{~cm}$ to $1 \mathrm{~m}$ in thickness.

Biotite granite: This unit corresponds to the Kabaing Granite which is widely exposed at well-known Mogok Gem Stone Track at north. It shows varying degrees of foliation and in places displays sheeted jointing. The biotite granite unit is the largest intrusive body in the Wabo area. It mainly occupies in the eastern part of the Wabo area. The biotite granite is younger than the surrounding metamorphic rocks. Generally, it intruded all metamorphic rocks in the Wabo area. It is dominantly composed of feldspar, quartz, and biotite. The exfoliation also occurs in the Wabo area that indicates a rounded hill configuration of the granites. Some aplite dikes occur within in garnet-biotite gneiss body at Myo Lwin and Zaw Min Prospects. Pegmatites are exposed as dykes and veins near the Wabo Village.

\section{Samples and Methods}

In this study, the following methods were undertaken: field investigation and 
sample collection, detailed petrography and textural studies, and X-ray fluorescence (XRF) spectroscopy and X-ray diffractometry (XRD). A total of twenty-five samples were collected from the existing underground working and from the surface of the Wabo deposit. Studies were undertaken on quartz veins from the Kyaw Soe Thu Prospect. Microscopic observations were conducted through thin sections with a thickness of approximately $0.03 \mathrm{~mm}$. In this research, we used a polarizing microscope Nikon Eclipse E600 POL equipped with an AdvanCan-U2II camera. The minerals were identified using a RIGAKU Ultima IV X-ray Diffractometer. Elemental analysis for the determination of chemical composition of ore minerals was performed by scanning electron microscope with an energy-dispersive X-ray analyzer (SEM-EDS) SU3500 of Hitachi High-Technologies Corporation at the Center of Advanced Instrumental Analysis, Kyushu University. Paragenetic relations were investigated in thin sections using a transmitted polarized microscopy. Ore minerals were examined in polished sections using a reflected light microscopy.

\section{Results}

\subsection{Textural Features of the Veins}

Gold bearing veins are hosted by the garnet-biotite gneiss at the Kyaw Soe Thu Prospect. The Kyaw Soe Thu Prospect lies at the top of mountain in the Wabo area. The host rocks are strongly altered adjacent to the mineralized quartz veins. Sometimes, remarkable striations are recorded on the surface of quartz veins. The veins range from $4 \mathrm{~cm}$ to $7 \mathrm{~cm}$ in thickness along metamorphic foliation planes of the host rocks as well as along fractures in the fault zones. The quartz veins in the Wabo deposit are dominantly composed of milky, green, sometimes blue, and white quartz. Among them, smoky and milky quartz are the most common in the Wabo deposit. White quartz is not dominant in the veins at the Kyaw Soe Thu Prospect. Mineralized chalcedonic quartz vein ranges from 1 $\mathrm{cm}$ to $3 \mathrm{~cm}$ in width (Figure $4(\mathrm{a})$ ). The vein is composed of fine quartz grains and some fragments of earlier quartz (Figure $4(\mathrm{~b})$ ). The band of Ankerite-quartz-sericite vein at Kyaw Soe Thu Prospect ranges from $1 \mathrm{~cm}$ to $2 \mathrm{~cm}$. (Figure 4(b) and Figure 4(c)) in width. The boundary is distinctly sharp between the chalcedonic quartz veins and the Ankerite-quartz-sericite veins. Ankerite and electrum are observed in the stage III veins cross-cutting the stage II chalcedonic quartz veins.

\subsection{Quartz Texture}

Quartz is a generally ubiquitous gangue mineral in the Kyaw Soe Thu Prospect. The hydrothermal quartz in the stage I thin crustiform quartz layer, in the stage II chalcedonic quartz vein, and stage III Ankerite-quartz-sericite veins displays distinctive textures associated with gold mineralization. Quartz commonly exhibits chalcedonic texture as well as saccharoidal and granular textures (Figure 5(a) and Figure 5(b)). Some of quartz crystals are elongated with subhedral to 

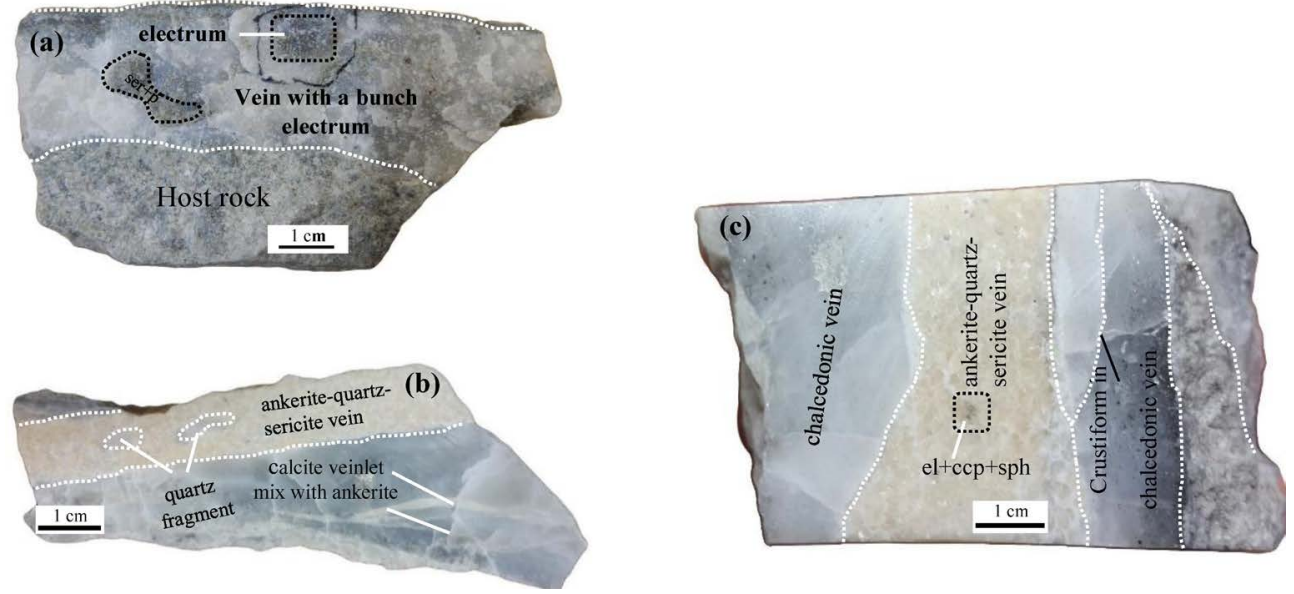

Figure 4. Photographs of stage II quartz vein samples and stage III ankerite-quartz-sericite vein samples. (a) KST-01 Host-rock fragment within the stage II quartz vein adjacent to host rock with clear and sharp contact. (b) KST-02 stage III ankerite-quartz-sericite vein with stage III calcite cross-cutting the stage II chalcedonic quartz vein. (c) KST-02 stage III ankerite-quartz-sericite vein with sharp boundary with stage I chalcedonic quartz vein and altered rock fragments with sericite. The rectangular by dotted in the central part of stage II chalcedonic quartz vein are shown in Figure 7. Abbreviation: el = electrum, $\mathrm{ccp}=$ chalcopyrite, $\mathrm{sph}=$ sphalerite, ser $=$ sericite.

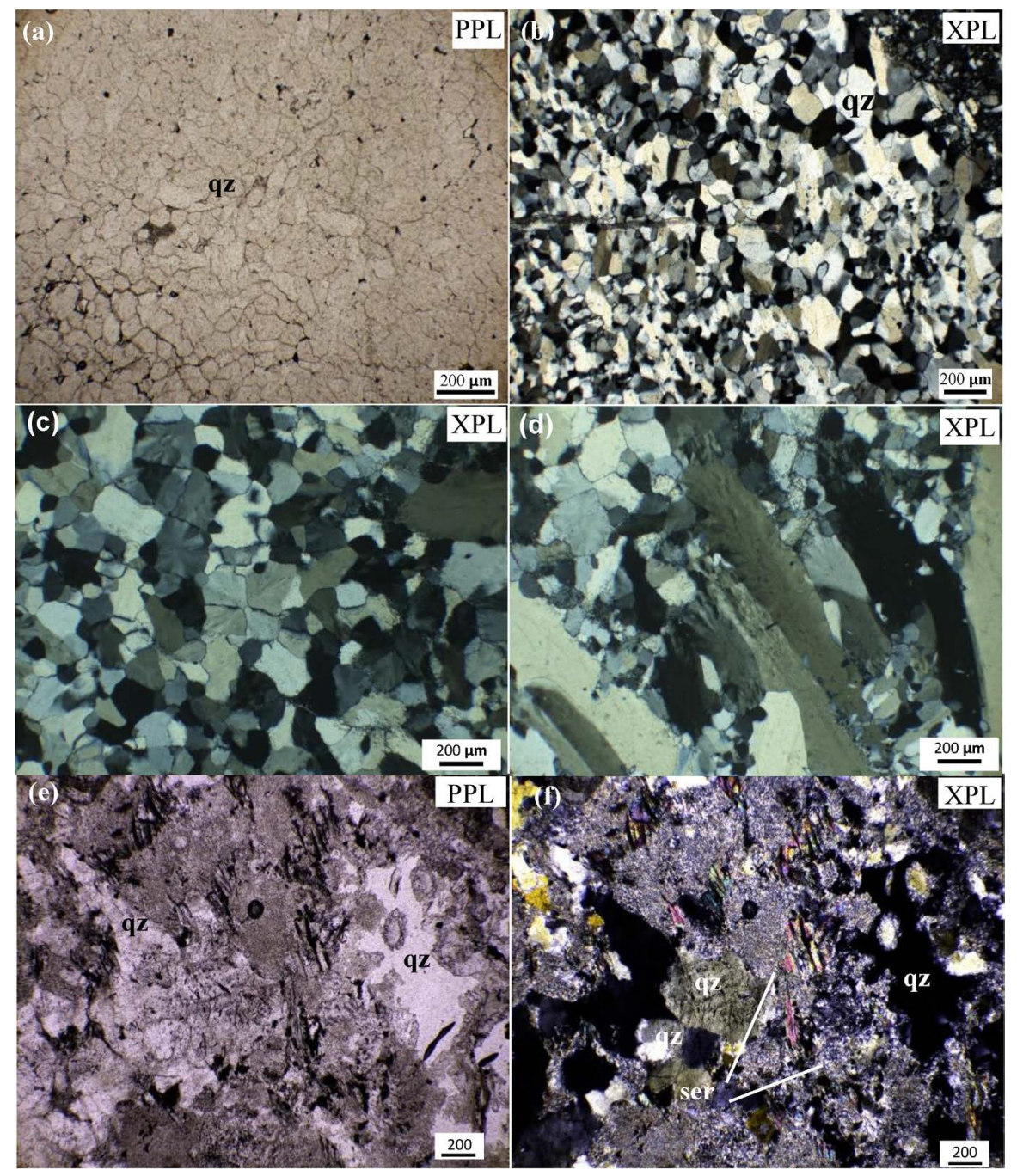




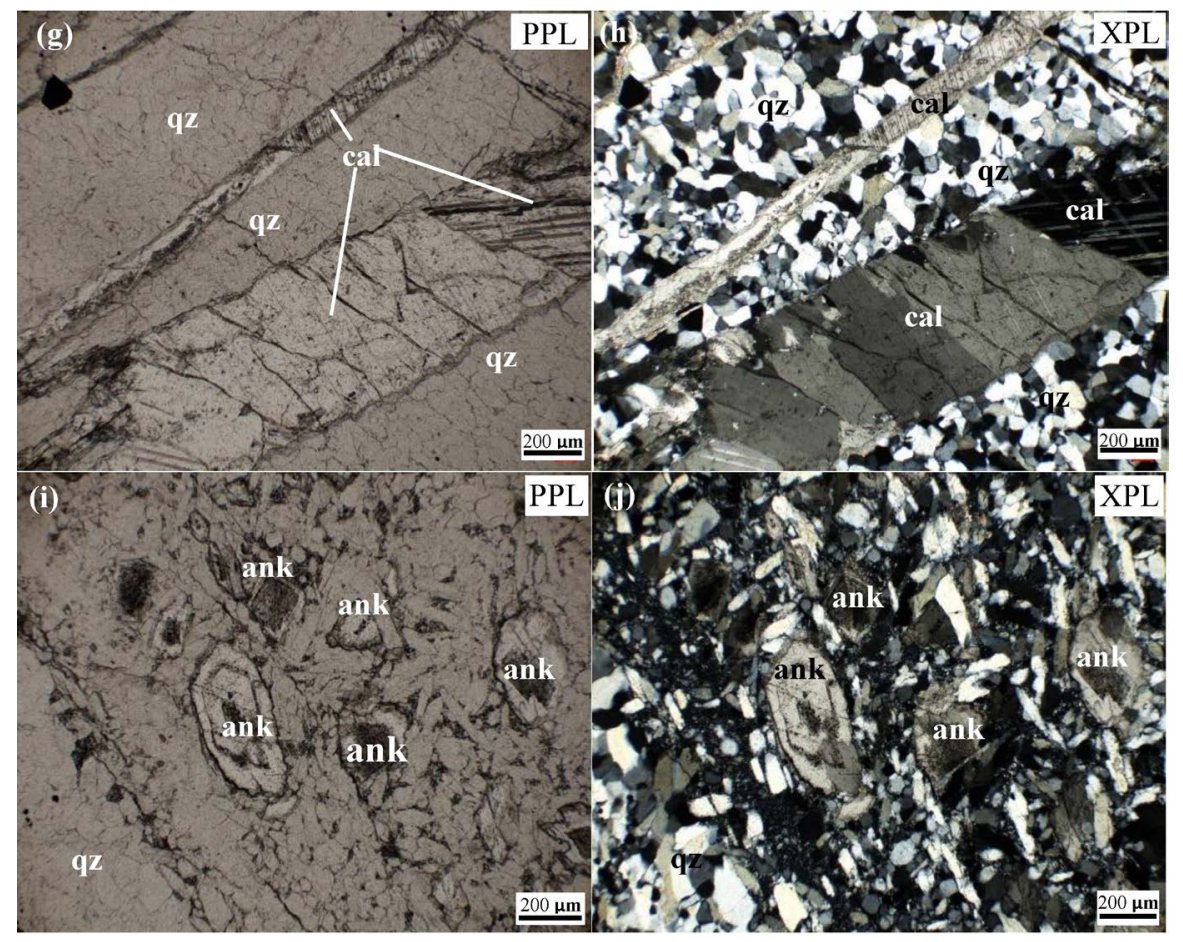

Figure 5. Photomicrographs of stage III ankerite-quartz-sericite vein crosscutting stage II chalcedonic quartz vein (KST-02). (a), (b) Massive quartz consisting of fine-grained granular quartz showing mosaic texture in stage II chalcedonic quartz vein. (c) Plumose quartz texture with feathery appearance in chalcedonic quartz vein. (d) Feathery quartz texture in stage II chalcedonic quartz vein. (e), (f) Sericite alteration of host rock fragments with quartz cement. Sericite also forms within the vein. (g), (h) Stage III calcite veinlet crosscutting stage II chalcedonic quartz vein. (i), (j) Rhombohedral ankerite with rhythmic overgrowth in stage III ankerite-quartz-sericite vein. Abbreviations: $q z=$ quartz, $\mathrm{cal}=$ calcite, ser $=$ sericite, ank $=$ ankerite $. \mathrm{XPL}=$ crossed nicols, $\mathrm{PPL}=$ plane polarized light.

anhedral habit. Micro-plumose texture (Figure 5(c)) exhibits a feathery (Figure 5(d)) appearance in some part of the stage I thin layered crustiform, stage II chalcedonic quartz vein and a few quartz crystals in the stage III Ankeritequartz-sericite vein. Within stage III Ankerite-quartz-sericite veins, prismatic quartz crystals are aligned parallel to ankerite crystals. Calcite occurs as cross-cutting radiating feathery quartz crystals. Crustiform thin layers are recognizable in stage I quartz. Electrum occurs in the stage II chalcedonic quartz veins and in the stage III Ankerite-quartz-sericite veins. An alteration mineral is sericite on the margin of quartz crystals of stage II chalcedonic veins and in the stage III Ankerite-quartz-sericite veins (Figure 5(e) and Figure 5(f)). Calcite occurred as the latest veinlets and cross cut in the stage II chalcedonic quartz vein (Figure 5(g) and Figure 5(h)).

\subsection{Ankerite-Quartz-Sericite Mineralized Veins}

The late hydrothermal mineralized vein or stage III Ankerite-quartz-sericite veins are dominantly composed of ankerite, quartz and small amount of sericite 
with a little calcite. The principal ore minerals in the stage III Ankerite-quartzsericite veins are electrum with minor sphalerite and chalcopyrite.

This study is the first-time documentation of the electrum-bearing Ankerite-quartz-sericite veins in the Wabo deposit area. Ankerite-quartz-sericite veins are found mainly as late veins. The ankerite observed at the Kyaw Soe Thu Prospect in hand specimen is light pink, milky, and pale brown in color. The Ankerite-quartz-sericite veins range in width from a centimeter to two centimeters.

All ankerite grains at the Kyaw Soe Thu Prospect are rhombohedral (Figure 5(i) and Figure 5(j)). Ankerite crystals reach over $400 \mu \mathrm{m}$ in size at most. Ankerite crystals occur together with the very thin calcite veinlet or cross-cutting veinlets. Zoning of the ankerite are observed in well-crystallized euhedral ankerite grains.

\subsection{Mineralization at the Kyaw Soe Thu Prospect}

Stage I mineralization: the earliest stage I consists of quartz, pyrite, and minor chalcopyrite. It occurs as chalcedonic quartz veins. Quartz crystals are fine-grained. The sulfide minerals appear to have formed as cementing the rock fragments in the veins. Sericite alteration occurred in this stage.

Stage II mineralization: Stage II represents the formation of quartz with sulfide and electrum. Quartz in the stage II veins is smoky and milky associated with pyrite, chalcopyrite and sphalerite. The quartz veins are composed of finegrained randomly distributed quartz crystals. The cluster of electrums ranges up to $1 \mathrm{~cm}$ size and mostly coarse grain (Figure 6(a)). The electrum grains are closely associated with pyrite (Figure 6(b)). A trace of sphalerite and chalcopyrite (Figure 6(c)) are also formed in stage II. Sometimes electrum grains are found on the margin of the pyrite grains (Figure 6(d)).

Stage III mineralization: Stage III consists of Ankerite-quartz-sericite veins. These veins crosscut the stage II mineralization veins. The stage III veins are composed of mainly ankerite, quartz, sericite, electrum, sphalerite and chalcopyrite. Electrum occurs as fine and anhedral grains in euhedral ankerite crystals (Figure 7(a) and Figure 7(b)). The electrum grain ranges from $20 \mu \mathrm{m}$ up to 200 $\mu \mathrm{m}$ in length. Sphalerite (Figure 7(b)) is fine-grained and anhedral and closely associated with fine-grained anhedral electrum. Chalcopyrite is also finegrained. Calcite veins cross-cut the stage II quartz veins. The margins of calcite veinlets with the stage II quartz veins are irregular. Some stage II quartz grains were intersected sharply by late calcite and Ankerite-quartz-sericite veins.

In some places fine- to coarse-grained Ankerite-quartz-sericite veins cross cut the chalcedonic quartz vein. These Ankerite-quartz-sericite veins are milky, pale brown in color and ankerite crystals are also visible with naked-eyes. Sometimes ankerite crystals are noticeably observed as a milky spot in the chalcedonic quartz vein. Some host rocks are found as breccia fragments preserved within the Ankerite-quartz-sericite veins. These Ankerite-quartz-sericite veins are 


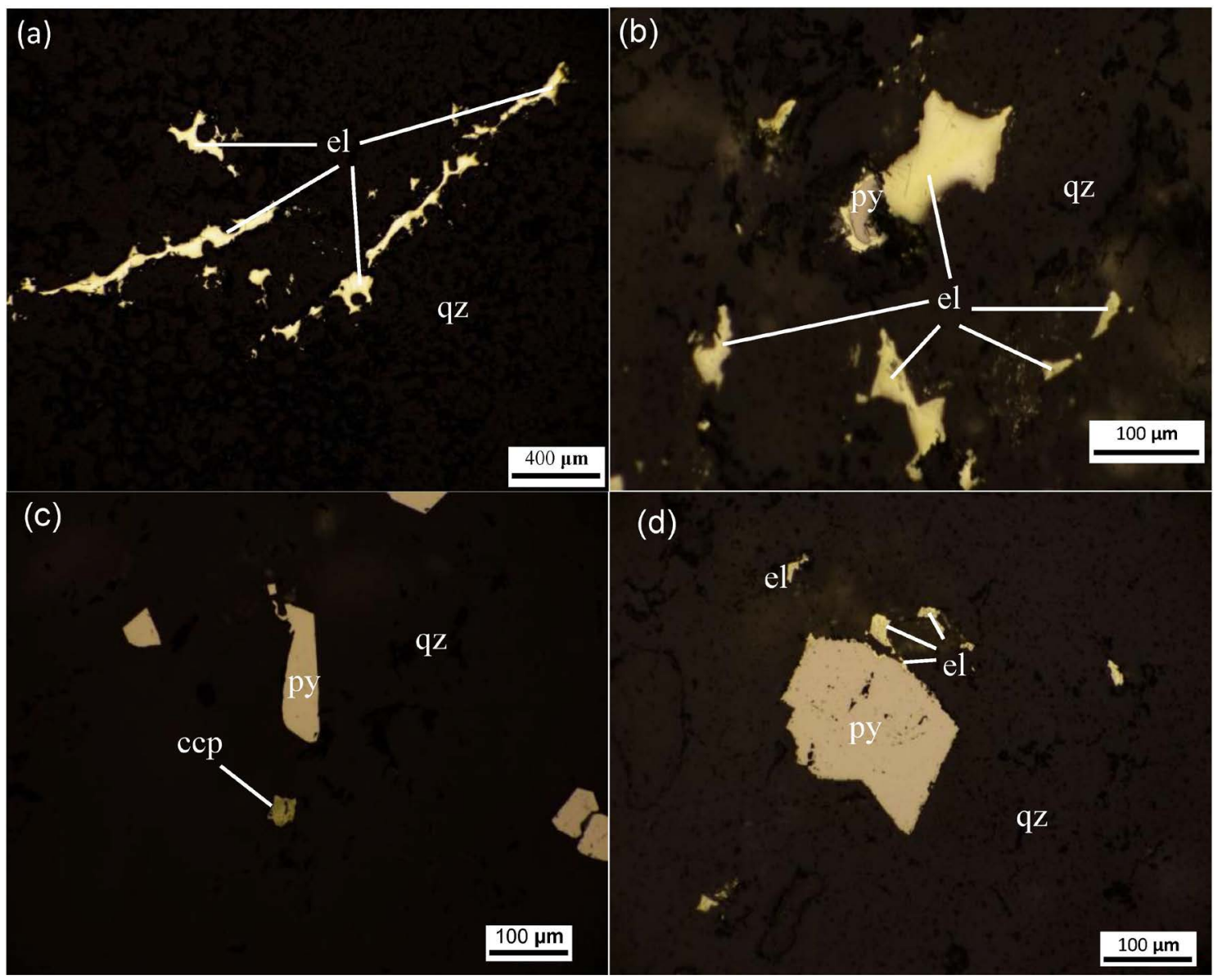

Figure 6. Photomicrographs of ore minerals in stage II quartz vein (KST-01) from the Kyaw Soe Thu Prospect. (a) Coarse-grained electrum. (b) Pyrite associated with electrum. (c) Anhedral pyrite formed fine-grained chalcopyrite. (d) Fine-grained electrum on the margin of pyrite. Abbreviations: py = pyrite, $c c p=$ chalcopyrite, el $=$ electrum, qz = quartz.

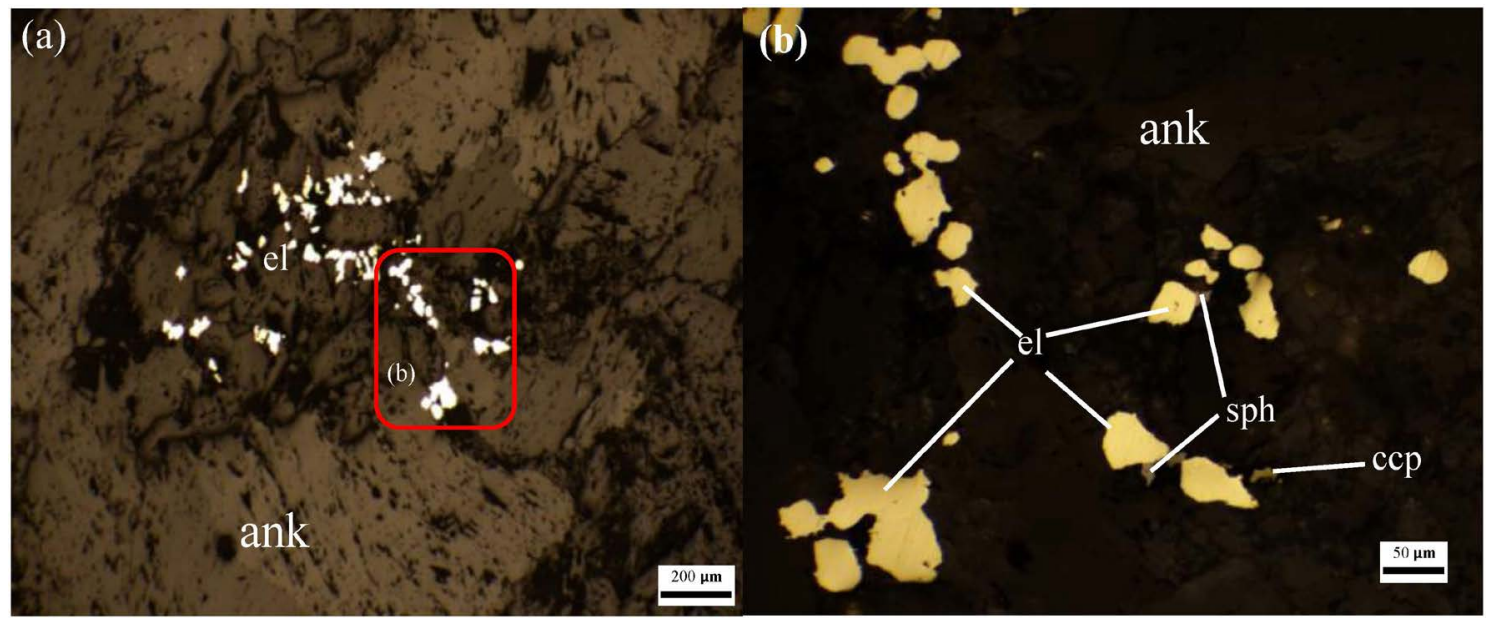

Figure 7. Photomicrographs of stage III ore minerals in the rectangular by dotted lines in the central part of the stage III ankerite-quartz-sericite vein crosscutting the stage II stage chalcedonic quartz vein shown in Figure 4(c) (KST-02) from the Kyaw Soe Thu Prospect. (a) Irregular electrum grains in stage III ankerite-quartz-sericite vein. Red rectangular is enlarged in (b). (b) Electrum grains associated with fine-grained sphalerite and chalcopyrite. Abbreviations: $\mathrm{ccp}=$ chalcopyrite, $\mathrm{sph}=$ sphalerite, $\mathrm{el}=$ electrum, ank = ankerite, $\mathrm{qz}=$ quartz. 
closely related with the gold mineralization. The irregular thin layers of calcite and Ankerite-quartz-sericite veinlets are also cross-cutting each other. It appears to be stage III mineralization events as calcite and Ankerite-quartz-sericite vein are cross-cutting the early chalcedonic quartz veins.

\subsection{Ore Mineralogy and Paragenesis}

The gold mineralization stages are classified into three stages (Figure 8). Stage I recognizes a thin crustiform quartz layers. It is the earliest sulfidation stage. It displays a smoky colored of thin crustiform quartz layers. It is mostly pyrite and a few fine-grained chalcopyrite. The pyrite crystals are mostly subhedral to anhedral. Stage II displays a massive chalcedonic quartz vein and exhibits a milky and white color. In stage II, the ore minerals are pyrite, electrum, chalcopyrite and a very few sphalerites. Pyrite commonly occurs as subhedral to anhedral form with a diameter of $100 \mu \mathrm{m}$ to $200 \mu \mathrm{m}$. In some places, it is closely associated with electrum. Chalcopyrite is fine-grained. Stage III indicates Ankerite-quartz-sericite vein phase. It mainly composes of ankerite with calcite and sericite. The ore minerals are electrum, pyrite, chalcopyrite and sphalerite. The principal gangue minerals are ankerite, quartz, and calcite. Sphalerite forms as small particle with electrum grain in the stage III Ankerite-quartz-sericite veins and also in the Stage II chalcedonic quartz veins. Chalcopyrite occurs as tiny particles at the edge of electrum grains in the stage III Ankerite-quartz-sericite veins. Chalcopyrite is not common in the Kyaw Soe Thu Prospect. Electrum dominantly occurs in not only in stage II chalcedonic quartz veins but also in the stage III Ankerite-quartz-sericite veins in the Kyaw Soe Thu Prospect. The morphology of electrum in quartz veins appears as a bunch of grains that are nearly $1 \mathrm{~cm}$

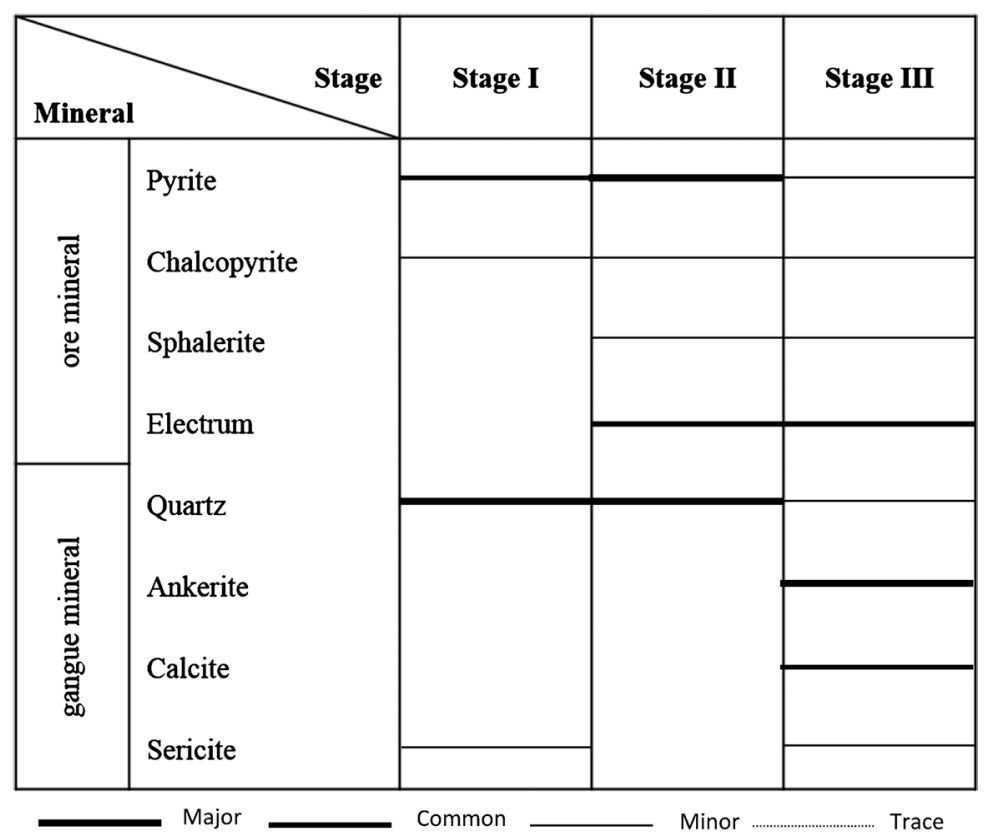

Figure 8. Paragenetic sequence of thin crustiform layer, chalcedonic quartz vein and ankerite-quartz-sericite vein in the Kyaw Soe Thu Prospect. 
wide in the stage II chalcedonic quartz veins.

Samples from stage II chalcedonic quartz vein and from stage III Ankeritequartz-sericite vein at the Kyaw Soe Thu Prospect were selected for SEM-EDX (Figure 9(a) and Figure 9(b)) to identify $\mathrm{Au}$ - Ag ratio by semiquantitative analysis. The $\mathrm{Ag} /(\mathrm{Au}+\mathrm{Ag})$ of electrum in the stage II chalcedonic quartz veins of the Kyaw Soe Thu Prospect ranges from 35 to 50 at\% (Figure 10). The $\mathrm{Ag} /(\mathrm{Au}+\mathrm{Ag})$ of electrum from the stage III Ankerite-quartz-sericite vein ranges from 30 to 50 at\% (Figure 10).

\section{Discussion and Conclusions}

The Wabo deposits are located in the Southern Himalayan Orogenic syntaxis and MMB [3] (Figure 1). The mineralization is hosted by amphibolite to granulite facies metamorphic rocks. It is formed in a structural deformed zone. Quartz veins with gold mineralization are widespread in the Wuntho area and on the western margins of the MMB and the Shan Plateau in the Slate Belt in Myanmar

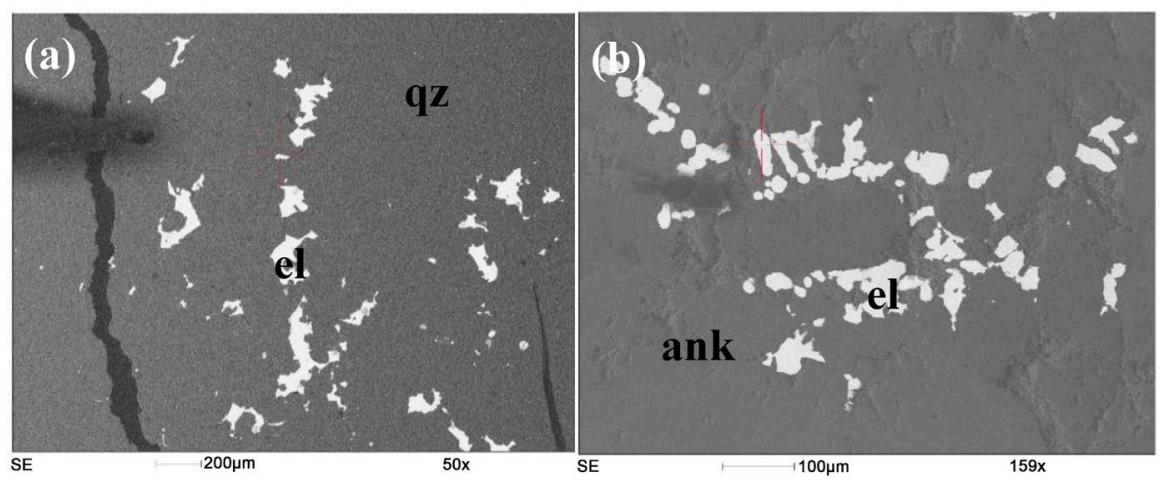

Figure 9. Backscattered image of the electrum grain for (a) chalcedonic quartz vein and (b) ankerite-quartz-sericite vein at the Kyaw Soe Thu Prospect. Abbreviation: el = electrum, $\mathrm{qz}=$ quartz, ank = ankerite.

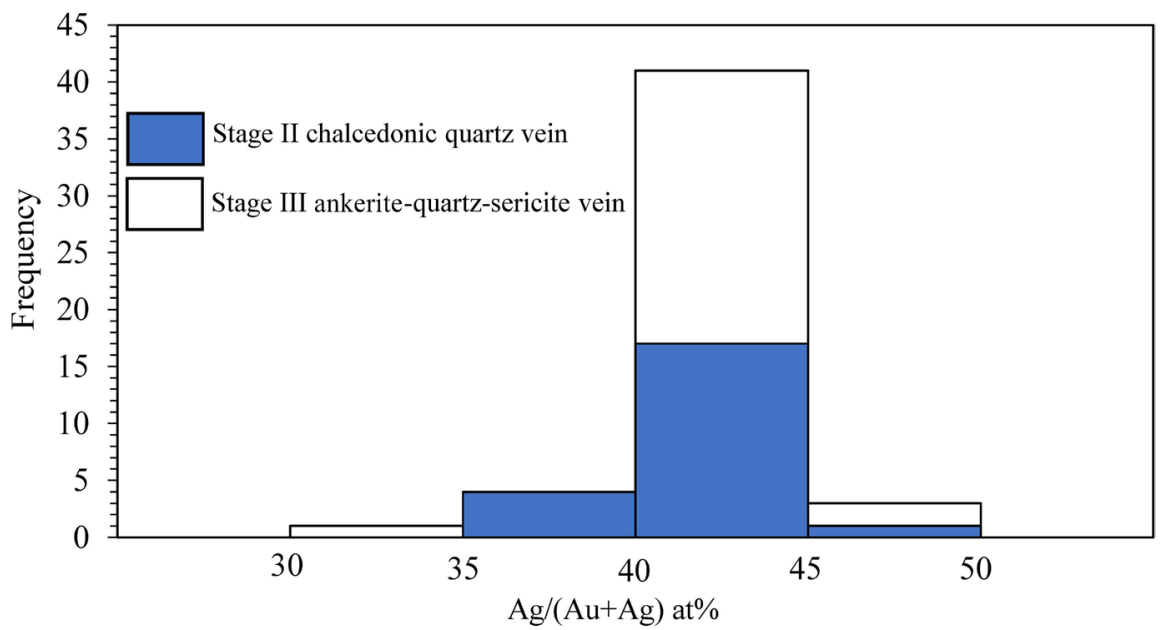

Figure 10. Frequency diagram of $\mathrm{Ag} /(\mathrm{Au}+\mathrm{Ag})$ (at\%) of electrum from stage II chalcedonic quartz vein (KST-01) and stage III ankerite-quartz-sericite vein (KST-02) from the Kyaw Soe Thu Prospect in the Wabo deposit. 
[4] (Figure 2). Mining of primary gold deposits has been conducted at Kyaukpazat to the North of Wuntho. In the Wuntho area and several areas along the western margin of the Shan Plateau, including Modi Taung, east of Tatkon and Phayaung Taung, NE of Mandalay are the significant gold occurrences. Although most of the primary mesothermal orogenic lode gold mineralization is commonly widespread [25], the Kyaukpahto deposits in the Wuntho area are a Carlin-like sediment-hosted deposit in Eocene turbiditic sandstones [2] [3]. The gold mineralization in the Wabo deposit in the MMB is hosted by the garnet-biotite gneiss, calc-silicate, marble and biotite granite. The veins are in some place massive veins, sheeted, networking each other, and exhibit saddle-reef and ribbons structures. The vein-type quartz gold mineralization at the Kyaw Soe Thu Prospect is formed in a fault system.

Chalcedony at the Kyaw Soe Thu Prospect is considered to have formed either by direct precipitation from hydrothermal solution or by transformation of amorphous silica to crystalline materials as suggested by [26]. Quartz with radiating texture shows a plumose texture. Some plumose textures are interpreted to reflect the crystallization of amorphous silica to quartz [27]. Textures formed by recrystallization of amorphous silica to chalcedony, such as the plumose (radiating) texture, are restricted to near-surface hydrothermal condition [28]. [26] indicated that these textures are loosely packed vitreous to milky fine-grained quartz cluster having the appearance of saccharoidal in hand specimens. [29] indicated that intermediate silica supersaturation with respect to quartz is needed for chalcedony to precipitate directly from solution. [29] also showed that chalcedony forms persistently only at temperature below about $180^{\circ} \mathrm{C}$.

Gold-bearing quartz veins are hosted by the metasedimentary rocks in the Wabo area. The nature of vein margins is generally sharp, and the veins are mostly steeply dipping. In the Kyaw Soe Thu Prospect, slickenside and striation are also observed along the mineralized quartz vein on the vein surfaces. The mineralization occurred in stage II chalcedonic quartz veins and stage III Ankerite-quartz-sericite vein.

We also highlight the evidence and nature of the stage II chalcedonic quartz vein crosscut by stage III Ankerite-quartz-sericite vein in the Wabo deposit. Zoning ankerite minerals is a good indicator of gold mineralization in the Kyaw Soe Thu Prospect. Based on the texture of the chalcedonic quartz veins, the mineralization at the Kyaw Soe Thu Prospect in the Wabo the gold deposit can be classified as a low-sulfidation epithermal deposit.

\section{Acknowledgements}

This work was financially supported by the ASEAN University Network/Southeast Asia Engineering Education Development Network (AUN/SEED-Net) and Japan International Cooperation Agency (JICA) scholarships. We would like to express our sincere gratitude to Society of Resource Geology for supporting overseas field work. We gratefully acknowledge to Prof. Akira Imai, Kyushu 
University, Japan for his kindness and support in guiding the present study and critical reading which had substantially improved the earlier versions of the original manuscript. We are deeply grateful to Prof. Khin Zaw, Centre of Ore Deposits and Earth Sciences (CODES), University of Tasmania, Australia for his valuable suggestions, and advices. We also acknowledge to Prof. Tin Aung Myint, for his suggestion to do a research work in the area and Associate Professor Zar Oo San, for his logical support provided during fieldworks.

\section{Conflicts of Interest}

The authors declare no conflicts of interest regarding the publication of this paper.

\section{References}

[1] Mitchell, A.H.G. (2018) Geological Belts, Plate Boundaries, and Mineral Deposits in Myanmar. Elsevier, Amsterdam, 509 p. https://doi.org/10.1016/B978-0-12-803382-1.01001-4

[2] Swe, Y.M., Aye, C.C. and Zaw, K. (2017) Gold Deposits of Myanmar. In: Barber, A.J., Zaw, K. and Crow, M.J., Eds., Myanmar. Geology, Resources and Tectonics, the Geological Society (London) Memoir, Vol. 48, the Geological Society of London, London, 557-572. https://doi.org/10.1144/M48.25

[3] Zaw, K., Barbar, A.J. and Crow, M.J. (2017) Overview of Mineralization Styles and Tectonic-Metallogenic Setting in Myanmar. In: Barber, A.J., Zaw, K. and Crow, M.J., Eds., Myanmar. Geology, Resources and Tectonics, the Geological Society (London) Memoir, Vol. 48, the Geological Society of London, London, 531-556. https://doi.org/10.1144/M48.24

[4] Searle, D.L. and Haq, B.T. (1964) The Mogok Belt of Burma and Its Relationship to the Himalayan Orogeny. Proceedings of the International Geological Conference, Delhi, Vol. 22, 132-168.

[5] Zaw, K., Sutherland, L., Yui, T.F., Meffre, S. and Thu, K. (2015) Vanadium-Rich Ruby and Sapphire within Mogok Gemfield, Myanmar: Implications for Gem Color and Genesis. Mineralium Deposita, 50, 25-39.

https://doi.org/10.1007/s00126-014-0545-0

[6] Thu, K. and Zaw, K. (2017) Gem Deposits of Myanmar. In: Barber, A.J., Zaw, K. and Crow, M.J., Eds., Myanmar. Geology, Resources and Tectonics, the Geological Society (London) Memoir, Vol. 48, the Geological Society of London, London, 497-529. https://doi.org/10.1144/M48.23

[7] Barley, M.E., Pickard, A.L., Zaw, K., Rak, P. and Doyle, M.G. (2003) Jurassic to Miocene Magmatism and Metamorphism in the Mogok Metamorphic Belt and the India-Eurasia Collision in Myanmar. Tectonics, 22, 1019.

https://doi.org/10.1029/2002TC001398

[8] Mitchell, A.H.G., Ausa, C.A., Deiparine, L., Hlaing, T., Htay, N. and Khine, A. (2004) The Modi Taung-Nankwe Gold District, Slate Belt, Central Myanmar: Mesothermal Veins in a Mesozoic Orogen. Journal of Asian Earth Sciences, 23, 321-341. https://doi.org/10.1016/S1367-9120(03)00138-X

[9] Zaw, K., Meffre, S., Lai, C.K., Burrett, C.M., Santosh, I.G., Manaka, T., Salam, A., Kamvong, T. and Cromie, P. (2014) Tectonics and Metallogeny of Mainland Southeast Asia-A Review and Contribution. Gondwana Research, 26, 5-30. 
https://doi.org/10.1016/j.gr.2013.10.010

[10] Zaw, K. (2019) Tectonic and Metallogenic Significance of Orogenic Gold Deposits in Mainland SE Asia. Annual Meeting of Society of Resource Geology, Abstract Volume, 26-27 June 2019, 46.

[11] Barber, A.J., Zaw, K. and Crow, M.J. (2017) The Pre-Cenozoic Tectonic Evolution of Myanmar. In: Barber, A.J., Zaw, K. and Crow, M.J., Eds., Myanmar. Geology, Resources and Tectonics, the Geological Society (London) Memoir, Vol. 48, the Geological Society of London, London, 687-712. https://doi.org/10.1144/M48.31

[12] Bunopas, S. (1981) Palaeogeographic History of Western Thailand and Adjacent Parts of South-East Asia: A Plate Tectonic Interpretation. Department of Mineral Resources, Geological Survey Paper No. 5 (Special Issue), Bangkok.

[13] Metcalfe, I. (1988) Origin and Assembly of South-East Asian Continental Terranes. Geological Society, London, Special Publications, 37, 101-118. https://doi.org/10.1144/GSL.SP.1988.037.01.08

[14] Searle, M.P., Noble, S.R., Cottle, J.M., Waters, D.J., Mitchell, A.H.G., Hlaing, T. and Horstwood, M.S.A. (2007) Tectonic Evolution of the Mogok Metamorphic Belt, Burma (Myanmar) Constrained by U-Th-Pb Dating of Metamorphic and Magmatic Rocks. Tectonics, 26, TC3014. https://doi.org/10.1029/2006TC002083

[15] Mitchell, A.H.G., Chung, S.L., Oo, T., Lin, T.H. and Hung, C.H. (2012) Zircon U-Pb Ages in Myanmar: Magmatic-Metamorphic Events and the Closure of a Neo-Tethys Ocean? Journal of Asian Earth Sciences, 56, 1-23. https://doi.org/10.1016/j.jseaes.2012.04.019

[16] Metcalfe, I. (2000) The Bentong-Raub Suture Zone. Journal of Asian Earth Sciences, 18, 691-712. https://doi.org/10.1016/S1367-9120(00)00043-2

[17] Zhang, J., Xiao, W., Windley, B.F., Wakabayashi, J., Cai, F., Sein, K., Wu, H. and Naing, S. (2018) Multiple Alternating Forearc- and Backarc-Ward Migration of Magmatism in the Indo-Myanmar Orogenic Belt since the Jurassic: Documentation of the Orogenic Architecture of Eastern Neotethys in SE Asia. Earth-Science Reviews, 185, 704-731. https://doi.org/10.1016/j.earscirev.2018.07.009

[18] Bertrand, G., Rangin, C., Maluski, H. and Bellon, H. (2001) Diachronous Cooling along the Mogok Metamorphic Belt (Shan Scarp, Myanmar): The Trace of the Northward Migration of the Indian Syntaxis. Journal of Asian Earth Sciences, 19, 649-659. https://doi.org/10.1016/S1367-9120(00)00061-4

[19] Mitchell, A.H.G., Htay, M.T., Htun, K.M., Win, M.N., Oo, T. and Hlaing, T. (2007) Rock Relationships in the Mogok Metamorphic Belt, Tatkon to Mandalay, Central Myanmar. Journal of Asian Earth Sciences, 29, 891-910. https://doi.org/10.1016/j.jseaes.2006.05.009

[20] Mitchell, A.H.G. (1993) Cretaceous-Cenozoic Tectonic Events in the Western Myanmar (Burma)-Assam Region. Journal of the Geological Society (London), 150, 1089-1102. https://doi.org/10.1144/gsigs.150.6.1089

[21] Zaw, K. (1990) Geological, Petrological and Geochemical Characteristics of Granitoid Rocks in Burma: With Special Reference to the Associated W-Sn Mineralization and Their Tectonic Setting. Journal of Southeast Asian Earth Sciences, 4, 293-335. https://doi.org/10.1016/0743-9547(90)90004-W

[22] Win, M.M., Enami, M. and Kato, T. (2016) Metamorphic Conditions and CHIME Monazite Ages of Late Eocene to Late Oligocene High-Temperature Mogok Metamorphic Rocks in Central Myanmar. Journal of Asian Earth Sciences, 117, 304-316. https://doi.org/10.1016/j.jseaes.2015.11.023

[23] Thein, M. and Win, S. (1970) The Metamorphic Petrology, Structures and Mineral 
Resources of the Shantaung-U-Thandawmywet Range, Kyaukse District. Union of Burma Journal of Science and Technology, 3, 487-514.

[24] Yonemura, K., Osanai, Y., Nakano, N., Adachi, T., Charusiri, P. and Zaw, T.N. (2013) EPMA U-Th-Pb Monazite Dating of Metamorphic Rocks from the Mogok Metamorphic Belt, Central Myanmar. Journal of Mineralogical and Petrological Sciences, 108, 184-188. https://doi.org/10.2465/jmps.121019a

[25] Chapman, R.J. and Mortensen, J.K. (2016) Characterization of Gold Mineralization in the Northern Cariboo Gold District, British Columbia, Canada, through Integration of Compositional Studies of Lode and Detrital Gold with Historical Placer Production: A Template for Evaluation of Orogenic Gold District. Economic Geology, 111, 1321-1345. https://doi.org/10.2113/econgeo.111.6.1321

[26] Dong, G.Y., Morrison, G.W. and Jaireth, S. (1995) Quartz Textures in Epithermal Veins, Queensland: Classification, Origin, and Implication. Economic Geology, 90, 1841-1856. https://doi.org/10.2113/gsecongeo.90.6.1841

[27] Sandar, M.V. and Black, J.E. (1988) Crystallization and Recrystallization of GrowthZoned Vein Quartz Crystals from Epithermal Systems: Implications for Fluid Inclusion Studies. Economic Geology, 83, 1052-1060. https://doi.org/10.2113/gsecongeo.83.5.1052

[28] Vearncombe, J.R. (1993) Quartz Vein Morphology and Implications for Formation Depth and Classification of Archaean Gold-Vein Deposits. Ore Geology Reviews, 8, 407-424. https://doi.org/10.1016/0169-1368(93)90036-X

[29] Morrison, G.W. (1990) Textural Zoning in Epithermal Quartz Veins. Klondike Exploration Services, Townsville, $21 \mathrm{p}$. 